\title{
THE EFFECT OF THE PRESENCE OF A RAM ON THE TIME OF OVULATION IN EWES
}

\author{
L. P. CAHILL, J. M. BUCKMASTER,* I. A. CUMMING, \\ R. A. PARR AND A. H. WILLIAMS \\ Department of Agriculture, S. S. Cameron Laboratory, and \\ *Reproduction Research Section, University of Melbourne, \\ S. S. Cameron Laboratory, Werribee, Victoria 3030, Australia
}

(Received 11th April 1974)

Intermittent teasing of ewes with a ram has been reported both to increase (Zeltobrjuh \& Rak, 1965) and to decrease (Parsons, Hunter \& Rayner, 1967) the interval from the onset of oestrus to ovulation.

Parsons et al. (1967) suggested that the presence of the ram influenced the time of ovulation in the ewe by altering the rate of the secretion of the LHreleasing factor. Cumming, Buckmaster, Blockey, Goding, Winfield \& Baxter $(1971,1973)$ investigated the relationship between the preovulatory release of $\mathrm{LH}$ and ovulation and found that ewes ovulated between 21 and $26 \mathrm{hr}$ (mean $23.5 \mathrm{hr}$ ) after the release of LH. Blockey (1971), however, found this interval to vary from 23 to $55 \mathrm{hr}$, the mean being $30 \mathrm{hr}$. While Cumming et al. (1973) removed the ewes from contact with the ram during oestrus, Blockey (1971) used intermittent teasing.

It is possible that association of the sexes during oestrus may explain the conflict between the results of Cumming et al. (1973) and Blockey (1971). The objective of this experiment was to determine the time intervals in ewes between the onset of oestrus and the release of $\mathrm{LH}$ and between the release of LH and ovulation under two systems of association with a ram during oestrus.

From 28 January 1973, 126 non-parous, 2- to $2 \frac{1}{2}$-year-old Merino ewes at the S.S. Cameron Laboratory, Werribee, were given injections of $20 \mathrm{mg}$ progesterone intramuscularly on 6 alternate days to synchronize oestrus.

The observations reported in this paper were of sixty-six ewes which exhibited oestrous behaviour from the 19th to 22nd day following the last progesterone injection.

The ewe flock was maintained in yards with three Corriedale rams fitted with harnesses and crayons. The rams were changed every $12 \mathrm{hr}$. Continual observations of mating behaviour were carried out and the time of the onset of oestrus was recorded. The onset of oestrus was defined as the time the ewe first stood for the ram while being mounted.

Once the onset of oestrus was detected, the ewe was moved to an adjoining shed and then allotted at random to one of two groups.

(1) Forty ewes were allotted to a 'ram-present' group. These ewes were exposed to a fresh ram every alternate hour for 2-hr periods during oestrus. At the end of oestrus, the ewes remained with one ram until they underwent 
laparotomy. Each ram was fitted with a different coloured crayon and inspection of the ewes' rumps for colour markings every $2 \mathrm{hr}$ enabled the duration of oestrus to be determined.

(2) Twenty-six ewes were allotted to a 'ram-absent' group. These ewes were moved a distance of $20 \mathrm{~m}$ from the presence and sight of any ram from the onset of oestrus until they underwent laparotomy.

At the onset of oestrus, and every hour thereafter for $16 \mathrm{hr}$, a $10-\mathrm{ml}$ blood sample was taken from the jugular vein. The samples were heparinized and centrifuged and the plasma was transferred to the laboratory where the $\mathrm{LH}$ concentration was determined using a 'rapid' assay technique (Cumming $e t$ al., 1973). When two consecutive samples of $\geqslant 20 \mathrm{ng} / \mathrm{ml}$ had been obtained from any ewe, it was assumed that the release of $\mathrm{LH}$ had commenced and the time of the first sample with a value of $\geqslant 20 \mathrm{ng} / \mathrm{ml}$ was taken as the onset of the $\mathrm{LH}$ release. When the onset of oestrus occurred after the onset of the release of $\mathrm{LH}$, the end of the $\mathrm{LH}$ release was determined, and, by subtracting the mean duration of the LH release found in the other ewes, the onset of the LH release

Table 1. The interval between the onset of oestrus and the release of $\mathrm{LH}$ and the percentage of ewes ovulating before laparotomy

\begin{tabular}{|c|c|c|c|c|}
\hline Treatment & $\begin{array}{l}\text { No. } \\
\text { of } \\
\text { ewes }\end{array}$ & $\begin{array}{l}\text { Interval from } \\
\text { LH release to } \\
\text { laparotomy (hr) }\end{array}$ & $\begin{array}{l}\text { Interval from onset } \\
\text { of oestrus to } L H \\
\text { release }(h r)\end{array}$ & $\begin{array}{c}\% \\
\text { Ewes } \\
\text { ovulating }\end{array}$ \\
\hline Ram present & $\begin{array}{l}21 \\
19\end{array}$ & $\begin{array}{l}23 \cdot 5 \\
26\end{array}$ & $1 \cdot 3$ & $\begin{array}{l}48 \\
95\end{array}$ NS. \\
\hline Ram absent & 26 & 26 & $2 \cdot 5$ & $93\}^{1 N}$. \\
\hline
\end{tabular}

N.S. $=$ not significant, $P>0.05$. There was no significant difference between groups for the interval from the onset of oestrus to $\mathrm{LH}$ release (L.S.D. $=1 \cdot 3 \mathrm{hr}$ ).

was estimated. At $23.5 \mathrm{hr}$ after the onset of the $\mathrm{LH}$ release, twenty-one ewes from the 'ram-present' group underwent laparotomy. At $26 \mathrm{hr}$ after the $\mathrm{LH}$ release, nineteen additional ewes from the 'ram-present' group and twenty-six from the 'ram-absent' group underwent laparotomy. Laparotomies were carried out under general anaesthesia using sodium thiamylal. The genital tract was exposed gently through a $10-\mathrm{cm}$ abdominal incision and each ovary was examined to determine whether or not an ovulation had occurred.

There was no significant difference in the interval from the onset of oestrus to the release of LH between the 'ram-present' and 'ram-absent' groups (Table 1). Sixteen of the sixty-six ewes in the experiment exhibited the onset of oestrus after the onset of the release of LH.

At $26 \mathrm{hr}$ after the release of $\mathrm{LH}$, there was no significant difference between groups in the proportion of ewes that had ovulated (Table 1). Ten of the twentyone ewes in the 'ram-present' group had ovulated by $23.5 \mathrm{hr}$ after the release of LH. The mean duration of oestrus for the forty ewes in the 'ram-present' group was $14.6 \pm 0.9 \mathrm{hr}$. Assuming that the mean time of ovulation was $23.5 \mathrm{hr}$ after the release of $\mathrm{LH}$, the mean interval from the end of oestrus to ovulation was $10.4 \pm 0.9 \mathrm{hr}$ with a range from 0.4 to $23.5 \mathrm{hr}$. 
The mean duration of oestrus was $13 \cdot 5 \pm 2 \cdot 1$ and $16 \cdot 4 \pm 2 \cdot 0 \mathrm{hr}$ for the ewes that had or had not ovulated respectively in the group that underwent laparotomy at $23.5 \mathrm{hr}$ after the release of LH. This difference was not significant.

The presence of a ram during oestrus was found to have no influence on the time of ovulation. This confirms the findings of Ivanow (1913) and McKenzie \& Terrill (1937) who reported that coitus had no effect on the time of ovulation. Our findings, however, are not in agreement with those of Parsons et al. (1967) and Zeltobrjuh \& Rak (1965).

At $26 \mathrm{hr}$ after the release of $\mathrm{LH}$, only three of the forty-five ewes had not ovulated, but two of these ewes ovulated during laparotomy. At $23.5 \mathrm{hr}$ after the $\mathrm{LH}$ release, $47.6 \%$ of the ewes had ovulated. Both results agree with the findings of Cumming et al. (1973) whose experiments were carried out in the later part of the breeding season whereas the present work was performed at the beginning of the breeding season.

These findings do not support the suggestion of Parsons et al. (1967) that the time of year may influence the effect of the ram on the time of ovulation.

A likely explanation of the different findings of Cumming et al. (1973) and Blockey (1971) exists in the difference between the techniques used to study ovarian activity. Cumming et al. (1973) made one observation only on each ewe whereas Blockey (1971) made repeated inspection of the ovaries, using an endoscopic technique with local anaesthesia. The stress involved with the procedures of endoscopy may have been an important factor influencing the time of ovulation.

Although the evidence presented here is inconclusive due to the small number of ewes involved and the variation in the individual durations of oestrus, it does support the hypothesis that the time of ovulation is independent of the duration of overt oestrus.

The authors wish to acknowledge the assistance of the officers of the Reproduction Section, Department of Agriculture, S.S. Cameron Laboratory, and to thank Dr J. K. Findlay and the staff of the Reproduction Research Section, University of Melbourne at the S.S. Cameron Laboratory for the technical assistance provided during the experiment. This work was financed by grants from the Australian Wool Research Trust Fund.

\section{REFERENCES}

Blockey, M. A. DE B. (1971) Studies on infertility in young ewes. M.V.Sc. thesis, University of Melbourne. Gumming, I. A., Buckmaster, J. M., Blockey, M. A. DE B., Goding, J. R., Winfield, C. G. \& Baxter, R. W. (1971) Constancy of interval between luteinizing hormone release and ovulation in the ewe. F. Reprod. Fert. 24, 134.

Gumming, I. A., Buckmaster, J. M., Blockey, M. A. De B., Goding, J. R., Winfield, G. G. \& Baxter, R. W. (1973) Constancy of interval between luteinizing hormone release and ovulation in the ewe. Biol. Reprod. 9, 24.

Ivanow, E. I. (1913) The relation between ovulation and heat in sheep. Preliminary communications. Zootechnical Station, Askisa Nova. (Cited by McKenzie \& Terrill, 1937).

McKenZIE, F. F. \& TERrill, G. E. (1937) Estrus, ovulation and related phenomena in the ewe. Univ. Mo. agric. Res. Bull. No. 264.

Parsons, S. D., Hunter, G. L. \& Rayner, A. A. (1967) Use of probit analysis in a study of the effect of the ram on time of ovulation in the ewe. F. Reprod. Fert. 14, 71 .

Zeltobrjuh, N. A. \& RAK, L. P. (1965) Biological stimulation of the reproductive function of the ewe. Anim. Breed. Abstr. 33, 448. 